\title{
The Role of Google Classroom in ELT
}

\author{
Sukmawati ${ }^{1, a^{*}}$, Nensia $^{2, b}$ \\ 1Department of English Education, Faculty of Teachers Training and Education, Universitas Megarezky, Makassar, 90222, Indonesia \\ 2Department of Hotel Administration, Sekolah Tinggi IImu Pariwisata Tamalatea, Makassar, 90000, Indonesia \\ a sukmar.dilla@gmail.com; b nensia.s@gmail.com \\ ${ }^{*}$ Corresponding Author \\ Whatsapp Number [081224885349]
}

How to Cite : Sukmawati, S., \& Nensia, N. (2019). The Role of Google Classroom in ELT. International Journal for Educational and Vocational Studies, 1 (2), $142-145$.

\section{ARTICLE HISTORY}

Received:12 March 2019

Revised: 18 April2019

Accepted: 20 May 2019

\section{KEYWORDS}

Google classroom;

English Language

Teaching and Learning;

\section{ABSTRACT}

Google Classroom is to offer a platform of blended learning in schools in order to simplify creating assignments and getting the grade out to the students in a paperless way. There are many facilities provided by Google classroom, they are: it will make easier for teachers to carry out learning activities, the intended learning is not only in class, but also outside the classroom because students can learn wherever and whenever by accessing google classroom online. Subject that relating to discuss as in the mobile that emphasize the acquisition of observational skills; and allow students to see the concept of teaching and learning material. The main purpose of the study is to investigate a role of Google classroom in English Language Teaching (ELT). The data was collected through an interview with 16 respondents. This study helped the decision makers of the higher educational institutions to have a better understanding of the role of using Google classroom by their students. It is assumed that it helped in measuring the level of students' attention to the previously mentioned technology.

This is an open access article under the CC-BY-SA license.

\section{INTRODUCTION}

Nowadays, development of technology is growing rapidly. The developments have been almost sectors. Economics, Politics and Education have applied technology. It can be predicted that many people have been addicted with information and communication technology (ICT). The development of ICT cannot be separated from information technology (IT) which is also growing. Information Technology is one of many the device used by managers in anticipating changes (Laudon and Laudon, 2014). With the development of IT, many people do innovation to make IT that can be used to facilitate other people in doing daily activities, ranging from sending messages, assignments and communicate online, search for and buy many things by online, order tickets and modes of transportation online and many others. Therefore, many aspects of human life are influenced by technological developments information where one of them is related to the learning process in the field education.

The current teaching and learning process is different from in the past time where classes that are held directly (face to face) or traditional method of teaching is teacher - cantered learning where lecturers use visual aids in the form of presentation slides, whiteboard and visualizer. Learning activities in the computer lab involves four major types of practical works: exercises, experiences, demonstrations and investigations. Therefore, the teachers need to be able to use the various technologies and also be able to design, compile, guide, and assess student projects. Resources and services need to be coordinated with colleagues and other professionals. This new role is challenging and requires the need for a different approach to teacher professional development. The isolation of typical teachers is formed with each other and the outside world must be eliminated given this very different form of education.

Distance education is a kind of education where teachers and students are separated and learning material is carried outthrough telecommunications systems. Many schools and universities throughout the world have used this learning system and have had successful experiences with it. The presence of educational technology is growing in the classroom. Teachers as educators must be prepared to work with this 
new technology, which plays an important role in learning and acquires a variety of cognitive knowledge so that educational technology must be incorporated into the future curriculum. The application of educational technology improves cognitive skills and characteristics.

The role of technology in the present teaching and learning process, every educator knows that learning is not something done only in class or handled by teacher. Today, it is often difficult to reach every student in the class using the same curriculum approach. The prospective of teachers has endless resources to guide students to higher levels of learning. The development of the use of computer technology in the last decade has had a profound effect on many schools and classrooms throughout the world, including Indonesia. The use of technology to improve education will bring benefits to the future in all areas of society.

In addition, the role of educators in the teaching process in schools is not same, but depends on institutional characteristics, teaching and learning conceptions, individual experiences, and teacher personality types. New technologies will not fundamentally change the role of educators, but have a major impact on how various teaching approaches can be applied in radically different technological and organizational environments. One of technologies is internet; it becomes an important thing in life. Almost all human needs achieved by internet. For example, we just move the finger to the gadget screen to choose things. It needs a few minute; we can get what we want to. It helps to save time and energy to obtain information. When internet introduced at the first time, it is few people having computer. Many people thought that internet related to pornographic. The government socialize internet through training or workshop, offices, schools from kindergarten to senior high school and many institutions. There is ICT centre applied in offices, schools and institutions. It eases user to access information that needed. In addition, internet can be accessed by mobile phone. It makes situation more comfortable and practical. It can be proved that many vendors introducing quota faster and cheaper. Consumers become large and access of informantion becomes faster. Information can be obtained whenever and anywhere.

One of sectors getting development of information and communication technology is education. Every several years, a high number of educational institutions are spending improving amounts of money to upgrade their systems for the intention of bridging the existing technological gaps in the curriculum (Buabeng-Andoh, 2012). It gives perception that technology can carry positive effect for students and teacher in teaching and learning process. Students from generation Zare participants from the learning process. Teacher-cantered learning is no longer suitable for this generation so it needs to change to a more student-cantered approach, especially for students who are very diverse in their abilities (Viridi. 2017).
Students are expected to more active by using method of learning given by teacher. For example, students are divided into some group to make a discussion. They can think and share ideas to obtaine new ideas. From discussion, it creates cooperative learning. There is a lot of prominence on combining technology in the classroom through innovative teaching strategies that focus on supporting students to achieve the desired learning objectives (Hwang, Lai, \& Wang, 2015). Technology facilitates increasing student engagement (Northey, Bucic, Chylinski, \&Govind, 2015) which is critical to obtain the desired learning objectives (Bolkan, 2015).

One of the ways that can be used to do the learning process online is to use Google Classroom. Google Classroom is to offer a platform of blended learning in schools in order to simplify creating assignments and getting the grade out to the students in a paperless way(Donald Yates, 2017). It is a popular Web 2.0 tools that offers a lot of interesting facilities and applications. It, like many other Web 2.0 tools, has potential for teaching and learning because of its unique built-in functions that offer pedagogical, social and technological affordances (Wang, Q et al: 2012). Google Classroom is a new tool introduced in Google Apps for Education in 2014. This classroom facilitates the teachers to create and organize assignments quickly, provide feedback efficiently, and communicate with their classes with ease online or blending learning style of teaching offers many advantages over the traditional classroom teaching style. The most influential advantages lie in its accessibility, students' scheduling flexibility, and adaptability for working (J. E. Gallagher, K: 2005). It takes into consideration the achievement of specific functions such as simplifying the students-teacher communication, and the ease of distributing and grading assignments. It provides the students with an opportunity to submit their work to be graded by their teachers online within the deadlines. Similarly, teachers can have a complete vision concerning the progress of each student, and they can return work along with the necessary comments so that the student can revise their assignments.

Accordingly, Google classroom can be effective for both the learners and faculty members due to its features. As for the students, it provides a stream line of communication and workflow for students. Being free of paper is a crucial factor in developing learning strategies. Thus, students can keep their files more organized and needless stored paperless in a single program [I. N. M. Shaharanee, et al: 2016]. The previously given view is supported by [S. Latif: 2016] who points out that Google classroom is useful in facilitating teaching and learning process. Students are able to use it with ease whenever the need arises. The teachers' most important task is to make students aware of the way of using the apps.

One of ways that we can be used to do the learning process online is to use Google Classroom. The use of Google Classroom can be via multiplatform which can be a computer and a device. Teachers and students can visit 
the site https://classroom.google.com or can download the application via the playstore on android or through the app store in IOS with the Google Classroom keyword. The use is free of charge, so that utilization can be done as needed. Through online learning, students are expected to be able to develop their abilities in a better direction.

\section{LITERATURE REVIEW}

Google Classroom is a google product that is connected with gmail, drive, hangout, youtube and a deep calendar. The many facilities provided by google classroom will make it easier for teachers to carry out learning activities. The intended learning is not only in class, but also outside the classroom because students can do learning wherever and whenever by accessing google classroom online.

Google classroom (or in Indonesian, ruang kelas Google) is a learning platform that can be devoted to any educational scope that is intended to help to find a way out of the difficulties experienced in making paperless assignments. This software has been introduced as part of Google Apps for Education (GAFE) since August 12, 2014. It is easier for teachers and students to carry out the learning process more deeply through this application. This is because both teachers and students can collect assignments, distribute assignments, and assess assignments without being bound by the lesson deadline.

It can work in unidirectional process as it can serve the teachers' strategies and styles on one hand and students' perception, understanding, and effective participation in different classroom skills. Learning activities in the mobile is one of the challenging in higher education. Google class room is a learning management system that can be used to provide teaching materials, integrated test assessments. It is different with learning media, the other advantages of Google class room media are problems of effectiveness and efficiency in learning.

'If we want to start to use Google Class Room, we first enter the Google account and then search for the Google product. After entering on our Google classroom account, we face three main menus, namely stream / flow, classwork / activities of students and people. Stream is a Google class facility that can be used to make announcements, discuss ideas or see the flow of tasks, material, quizzes on topics taught by the teacher. Classwork can be used by the teacher to make test or questions, pre-test, quiz, upload material and doing reflection. For the people of menu, the teacher can invite students to use the access code that is already available on the people bar, while to invite other teachers as collaborators is enough to invite the teacher through each email of students. The materials will be uploaded on the classwork bar can be in the form of word, excel, power point, pdf or video files. It is done by the teacher to accommodate any differences in thinking, background of pre knowledge, and differences in learners learning styles. Google classroom learning media has been proven to support the success of teaching and learning because it can be combined with any model or method.

The easiest way to access Google classroom through play store, we type Google classroom, download the application, open and install it on each cell phone or android. The display form that appears on hand phone or android is a green square with Google class room. After successfully downloading, opening and installing Google Class Room, it can be started by clicking the "+"sign on the top toolbar. There are two options that will appear, namely making classes and joining classes. The teacher can make a class by typing the name of the class, the subject and the subject of learning that is faced by students.

\section{METHODS}

This research applied descriptive qualitative in which the subject was the second semester English students at Megarezky University. To complete data, the researcher interviewed students who used google classroom. Then, documentation including documents in google classroom used as supporting data.In analyzing data, the researcher elaborated and described the data.

\section{RESULTS AND DISCUSSION}

The resercher found that students who used google classroom felt excited using online learning. This application can be accessed easily. It can be found by gadget such as computer, laptop, notebook and handphone. In addition, students can focus on their discipline because lecturer gives time to submit the assignment. Students can see the instruction of classwork about what the topic and deadline of assignment are. If the students are late to submit, notification will give information in lecturer's account. Next, students easily submit assignment anywhere via handphone. The forms were word, audio, Their knowledge become more increase about online learning. Students are faster to obtain information. Google classroom become useful media to learn English.

By google classroom, students and lecturer can make interaction. There was also a private comment. Here, students communicate with a lecturer anything relating to the topic. There was also space to interact between student and other students.

Lecturer can upload materials that were used in the classroom. Before meeting take place, students can see the outline of material and download material directly in google classroom. The material can be form of word, Powerpoint and pdf. Students can see previous material when they forgot. Based on research, many student typed word directly via handphone. They thought that it was easier than should open laptop and wait conneting internet. 
Last, students can know result of assignment. A lecturer will give grade and students can see directly from their google classroom. In line with the research, it was related to [S. Latif: 2016] who points out that Google classroom is useful in facilitating teaching and learning process.

\section{CONCLUSION}

Based on the result of the research, it researcher can be concluded that google classroom has roles in english learning teaching. It was proved that students can focus on their discipline because the assignments have deadline. Then, students easily submit assignment anywhere via handphone. Furthermore, there is an interaction between lecturer and students in a private comment. There is also for student and other students. Therefore, Google classroom has an important role in english learning teaching.

\section{REFERENCES}

Adiyanti, D.R. (2013). The Drought Selection in several varieties of citrus rootstock inVitro. [Skripsi].InstitutPertanian Bogor. Bogor.

Aryati, V. (2011). The Method of Fast Controlled Expolsion to identify early genotype padigogo (Oryza sativa L.) toleran kekeringan. [Skripsi.Institut Pertanian Bogor. Bogor.

Donald Yates. (2017). Google Classroom Easiest Teacher's Guide to Master Google Classroom. Copyright 2017 by Donald Yates - All rights reserved. https://www.pdfdrive.com/google-classroom-easiest-te achers-guide-to-master-google-classroom-google-classr oom-app-google-classroom-for-teachers-google-classro om-book-1-d158049011.html. accessed on 27 April 2019.

Fadillah, Syarifah. (2009). " Mathematical Problem Solving Ability in Mathematics Learning. "National Seminar on Research, Education and Application MIPA. Yogyakarta: Fakultas MIPA, Universitas Negeri Yogyakarta. 553-558.

Gunawan, Fransiskus Ivan. (2016). Mendidik GenerasiNet. Yogyakarta: Sanata Dharma University Press.

I. N. M. Shaharanee, J. Et al. (2016) "The Application of Google Classroom as a Tool for Teaching and Learning," vol. 8, no. 10, pp. 5-8.

J. E. Gallagher, K. Et al. (2005). "Webbased vs . Traditional Classroom Instruction in Gerontology": A Pilot Study," vol. 79, no. 3, pp. 1-10.

Laudon, Kenneth C, and Jane P Laudon. (2014). Management Information Systems: Managing Digital Firm. 13thed. New Jearsey: Pearson Education Inc. f dan R \& amp; D.Bandung: Alfabeta.

S. Latif. (2016). Learning Engagement in Virtual Environment. vol. 148, no. 11, pp. 7-13.

Viridi, et al. (2017). " Teacher Research to Prepare Generation $\mathrm{Z}$ in Indonesia." SEAMEO QITEP in Science. Bandung: P4TK IPA. 1-2.

Wang, Q, et al. (2012). Using the Facebook group as a learning management system: An exploratory study. Br. J. Educ. Technol, 43(3): 428-438.

Sugiyono. (2008). Metode Penelitian Kuantitatif Kualitati 